\title{
Kecepatan dan Hambatan Rekolonisasi Musuh Alami Setelah Aplikasi Insektisida di Pertanaman Padi
}

\author{
Baehaki Suherlan Effendi ${ }^{1,2 *}$, Eko Hari Iswanto ${ }^{1}$, Dede Munawar ${ }^{1}$ dan Nono Sumaryono ${ }^{1}$ \\ ${ }^{1}$ Balai Besar Penelitian Tanaman Padi Jl. Raya 9, Sukamandi, Subang, Jawa Barat \\ ${ }^{2}$ Pupuk Indonesia Holding Company \\ *Alamat korespondensi: baehakise@yahoo.co.id
}

\section{ABSTRACT \\ Recolonization of Natural Enemies after Insecticide Application in Rice Planting Area}

The study to assess recolonization of natural enemies after insecticide application in rice planting area was carried out in the wet season of 2013 at Karawang Regency. The application of several insecticides of rynaxypyr, fipronil, dinotefuran, pymetrozine, imidacloprid, and BPMC was conducted when brown plant hopper population was rising and yellow stem borer flight was occurring. Observation of natural enemies was carried out on 1, 3, 5, 7, 10, 15, and 21 days after application (DAA) using sweep net for 4 swings per plot. The results showed that spiders were relatively safe to the rynaxypyr and fipronil insecticides with hampered recolonization index (HRI) of very light and light where recolonization occurred on 1 DAA. All tested insecticides highly affected Telenomus rowani with HRI of heavy to very heavy that this parasitoid recolonized at $7 \mathrm{DAA}$. On the other hand, all insecticides showed low influence on the recolonization of Tetrastichus schoenobii with HRI from unhampered to light hamper and the recolonization occurred on 1 DAA. The effect of rynaxypyr, fipronil, imidacloprid and BPMC application on Oligosita sp. and Anagus sp. recolonization was categorized to be low with HRI of light hamper that the recolonization happened at $1 \mathrm{DAA}$ and $5 \mathrm{DAA}$, respectively. The insecticides of fipronil and BPMC were considered to slightly hamper the chironomid with the light value of the HRI and the chironomid recolonized at 1 DAA on fipronil and 3 DAA on BPMC.

Keywords: Effect of insecticides, Recolonization of natural enemy, Rice

\begin{abstract}
ABSTRAK
Penelitian rekolonisasi musuh alami setelah aplikasi insektisida di pertanaman padi dilakukan pada musim hujan 2013 di Kabupaten Karawang. Aplikasi insektisida berbahan aktif rinaksipir, fipronil, dinotefuran, pimetrozin, imidakloprid, dan BPMC dilakukan saat populasi hama wereng coklat meningkat, sementara penerbangan penggerek batang padi kuning sedang berlangsung. Pengamatan terhadap musuh alami menggunakan jaring serangga sebanyak 4 ayunan per petak pada 1, 3, 5, 7, 10, 15, dan 21 hari setelah aplikasi (HSA). Hasil penelitian menunjukkan bahwa laba-laba relatif aman terhadap insektisida rinaksipir dan fipronil dengan nilai indeks hambatan rekolonisasi (IHR) kedua insektisida tersebut sangat ringan dan ringan dengan kecepatan rekolonisasi laba-laba pada 1 HSA. Semua insektisida menekan sangat tinggi terhadap Telenomus rowani dengan IHR berat sampai sangat berat dan rekolonisasi parasitoid tersebut dinilai lambat yaitu 7 HSA. Insektisida menekan sangat rendah terhadap Tetrastichus schoenobii dengan IHR dari tidak ada hambatan sampai hambatan ringan dan kecepatan rekolonisasinya terjadi pada 1 HSA. Tekanan insektisida rinaksipir, fipronil, imidakloprid, dan BPMC terhadap Oligosita sp. dan Anagus sp. agak rendah dengan IHR ringan dan kecepatan rekolonisasi Oligosita sp. pada 1 HSA dan Anagrus sp. pada 5 HSA. Insektisida fipronil dan BPMC agak menekan chironomid dengan nilai IHR ringan dan kecepatan rekolonisasi 1 HSA pada fipronil dan 3 HSA pada BPMC.
\end{abstract}

Kata Kunci: Pengaruh Insektisida, Rekolonisasi musuh alami, Padi 


\section{PENDAHULUAN}

Di Indonesia pada saat ini ada dua hama utama yang sering merusak pertanaman padi yaitu penggerek batang padi dan hama wereng. Penggerek batang padi yang menjadi kendala di lahan irigasi maupun di lahan lebak dan pasang surut terdiri dari lima spesies yaitu penggerek padi kuning Scirpophaga (Tryporiza) incertulas (Walker), penggerek padi putih Scirpophaga (Tryporyza) innotata (Walker), Chilo suppressalis Walker, Chilo Polychrysus (Meyrick), dan Sesamia inferens (Walker). Perkembangan penggerek batang padi di lapangan dihambat oleh kinerja musuh alami terutama parasitoid Tetrastichus schoenobii, Telenomus rowani, Telenomus dignus, dan Trichogramma japonicum yang menghambat penetasan telur (Baehaki, 2013).

Hama wereng yang terkenal dan banyak merusak tanaman padi adalah hama wereng coklat, Nilaparvata lugens Stal., sedangkan hama wereng punggung putih, Sogatella furcifera Horvarth hanya sewaktu-waktu menimbulkan kerusakan. Musuh alami yang dapat mengendalikan kedua hama wereng tersebut berupa parasitoid, predator dan patogen. Parasitoid yang menyerang telur dan banyak didapatkan di lapangan ialah Anagrus sp. dan Oligosita sp., sedangkan predator telur antara lain adalah Cyrtorhinus lividipennis. Predator yang ditemukan di persawahan yang memakan nimfa dan imago wereng yaitu laba-laba (Pardosa (Lycosa) pseudoannulata, Tetragnatha maxillosa, Clubiona javonicola, Araneus inustus, Calitrichia formosana, Oxyopes javanus, dan Argiope catenulate), Ophionea nigrofasciata dan Paederus fuscifes (Baehaki \& Widiarta, 2008). Demikian juga banyak ditemukan predator dari coccinelid dan libellulid.

Di pertanaman padi selain didapatkan hama, predator dan parasitoid, juga didapatkan serangga netral (lalat ephytrid, colembola dan chironomid ) yang berfungsi sebagai suplemen makanan predator. Serangga netral ini banyak berkembang pada bahan organik atau pada sisa hasil panen. Bahan organik memperkaya populasi serangga netral untuk makanan laba-laba dan capung sebagai musuh alami yang berguna menekan hama (Baehaki et al., 2012). Serangga chironomid selain untuk suplemen makanan predator, juga digunakan sebagai bahan bioasai untuk menentukan kadar insektisida di lahan sawah (Faria et al., 2007).

Pada saat ada ledakan hama yang mengindikasikan pengendalian menggunakan varietas tahan, budidaya yang baik, dan manipulasi musuh alami tidak berhasil, maka pengendalian harus didukung oleh penggunaan pestisida untuk menekan hama ketingkat yang tidak membahayakan. Penggunaan insektisida sangat baik untuk secepatnya menghentikan perkembangan hama, namun di lain pihak ada pengaruh baik langsung maupun tidak langsung terhadap terbunuhnya musuh alami. Pada situasi penyelamatan hasil padi, penggunaan insektisida saat mencapai ambang ekonomi tidak dapat dihindarkan dan perlu digunakan untuk mencegah meluasnya serangan hama.

Penggunaan insektisida sebagai faktor utama dalam pengendalian hama serangga akan menyebabkan hilangnya keanekaragaman hayati di agro-ekosistem (Boutin et al., 2009; Geiger et al., 2009; Das et al., 2010; Falcone \& DeWald, 2010). Dampak negatif insektisida pada musuh alami di sawah tropis telah didokumentasikan dari penelitian yang dilakukan di Asia (Gangurde, 2007). Di Jalur Pantura, telah terjadi pengurangan biodiversitas serangga hama karena hilangnya serangga Thaia oryzicola dan Recilia dorsalis. Hal ini akan memengaruhi atau mengubah rantai makanan di ekosistem sawah menyebabkan ketidakseimbangan biologi dan banyak terjadi ledakan hama pada tanaman budidaya.

Sehubungan dengan hal tersebut di atas dalam usaha menggabungkan pengendalian kimia dan musuh alami, perlu informasi pengaruh insektisida terhadap pemulihan (recovery) musuh alami yang diukur dengan kecepatan dan indeks hambatan rekolonisasi. Data rekolonisasi musuh alami sangat penting karena walaupun insektisida berpengaruh negatif, bila rekolonisasi musuh alami cepat, maka insektisida yang digunakan akan mendukung penerapan pengendalian hama terpadu di Indonesia. Penelitian bertujuan mengukur kecepatan dan hambatan rekolonisasi musuh alami hama padi dalam rangka menentukan insektisida yang selektif.

\section{BAHAN DAN METODE}

\section{Pengaruh Insektisida terhadap Musuh Alami dan Serangga Netral}

Penelitian dilakukan di Kabupaten Karawang-Propinsi Jawa Barat pada musim tanam padi musim hujan (MH) 2013. Percobaan menggunakan Rancangan Acak Kelompok dengan 7 perlakuan insektisida yang diulang 4 kali. Perlakuannya adalah penggunaan 6 insektisida generasi baru yang banyak dipakai oleh petani yaitu 
insektisida berbahan aktif rinaksipir (golongan antranilik diamid), fipronil (pirazol), dinotefuran (neonikotinoid), pimetrozin (piridin azometin), dan imidakloprid (neonikotinoid), serta generasi lama BPMC (karbamat) yang dibandingkan dengan kontrol tanpa insektisida. Dosis formula insektisida rinaksipir, fipronil, dinotefuran, pimetrozin, imidakloprid, dan BPMC berturut-turut adalah 500 $\mathrm{ml}, 24 \mathrm{~g}, 500 \mathrm{~g}, 500 \mathrm{~g}, 30 \mathrm{~g}$, dan 11/ha.

Bibit padi Ciherang umur 21 hari ditanam dalam petak berukuran $8 \mathrm{~m}$ x $10 \mathrm{~m}$ dengan jarak tanam $25 \mathrm{~cm} \mathrm{x} 25 \mathrm{~cm}$. Insektisida diberikan saat populasi wereng coklat meningkat bersamaan dengan penerbangan penggerek batang padi kuning. Pengamatan dilakukan pada 1, 3, 5, 7, 10, 15 dan 21 hari setelah aplikasi menggunakan jaring serangga (sweep net) sebanyak 4 ayunan untuk mengamati laba-laba predator, Cyrtorhinus lividipennis, Paederus fuscifes, Ophionea nigrofasciata, Coccinella arcuata, Tetrastichus sheonobii, Telenomus rowani, Angrus sp. dan Oligosita sp. Data diolah dengan metode analisis sidik ragam (ANOVA) dan perbedaan antara perlakuan untuk menentukan pengaruh insektisida terhadap musuh alami menggunakan uji jarak berganda Duncan (Duncan's Multiple Range Test $=$ DMRT) pada tarap nyata $5 \%$.

\section{Kecepatan Rekolonisasi Musuh Alami dan Serangga Netral Serta Daya Hambat Insektisida}

Dari analisis sidik ragam dapat diketahui kecepatan rekolonisasi musuh alami dan indeks hambatan insektisida terhadap rekolonisasi. Kecepatan rekolonisasi musuh alami adalah waktu tercepat dari musuh alami tersebut berada lagi di pertanaman padi setelah aplikasi insektisida, diukur dengan populasi musuh alami ( $\mathrm{P}_{\text {musuh alami }}$ ) yang datang di petak perlakuan setelah aplikasi insektisida tidak berbeda dengan populasi musuh alami pada petak kontrol ( $\mathrm{P}_{\text {kontrol}}$ ) berdasar analisis sidik ragam, $\mathrm{P}_{\text {kontrol }}$-LSD5\% > $\mathrm{P}_{\text {musuh alami }}>\mathrm{P}_{\text {kontrol. }}$

Indeks hambatan rekolonisasi musuh alami akibat insektisida diukur dengan hambatan insektisida dari beberapa pengamatan. Bila populasi musuh alami saat pengamatan pada petak perlakuan berbeda dan lebih rendah dibanding pada petak kontrol, maka rekolonisasinya terhambat (hampered $=H$ ). Bila populasi musuh alami saat pengamatan pada petak perlakuan sama atau berbeda dan lebih tinggi dibanding musuh alami pada petak kontrol, maka rekolonisasinya tidak terhambat (unhampered $=U H$ ). Indeks hambatan rekolonisasi (IHR) musuh alami ditentukan dengan formula sebagai berikut:

\author{
IHR $=\frac{\sum \mathrm{H}_{\mathrm{i}}}{\operatorname{Total}\left(\mathrm{H}_{\mathrm{i}}+\mathrm{UH}_{\mathrm{i}}\right)} \times 100 \%$ \\ Total $\left(\mathrm{H}_{\mathrm{i}}+\mathrm{UH}_{\mathrm{i}}\right)$ \\ $\mathrm{i}=$ waktu pengamatan \\ Kriteria indeks hambatan rekolonisasi musuh alami \\ adalah: \\ $\begin{array}{ll}0 \% & =\text { tidak ada hambatan } \\ 0 \%<\mathrm{x} \leq 25 \% & =\text { hambatan sangat ringan } \\ 25 \%<\mathrm{x} \leq 50 \% & =\text { hambatan ringan } \\ 50 \%<\mathrm{x} \leq 75 \% & =\text { hambatan berat } \\ 75 \%<\mathrm{x} \leq 100 \% & =\text { hambatan sangat berat }\end{array}$
}

\section{HASIL DAN PEMBAHASAN}

Pada MH 2013 di pertanaman padi Karawang didapatkan musuh alami wereng coklat, musuh alami penggerek batang padi dan serangga netral. Musuh alami yang terjaring adalah laba-laba yang merupakan predator polifag, Telenomus rowani dan Tetrastichus schoenobii sebagai parasitoid pada telur penggerek padi kuning, Oligosita sp. dan Anagrus sp. sebagai parasitoid pada telur wereng coklat. Didapatkan juga chironomid yang merupakan serangga netral makanan predator.

\section{Pengaruh Insektisida terhadap Musuh Alami dan Serangga Netral}

Pada pengamatan 1 hari setelah aplikasi (HSA) populasi laba-laba predator pada perlakuan insektisida dinotefuran, pimetrozin dan imidakloprid lebih rendah dan berbeda nyata dengan kontrol, sedangkan pada perlakuan rinaksipir, BPMC dan fipronil tidak berbeda dengan kontrol. Pada pengamatan 3 HSA populasi laba-laba predator pada perlakuan insektisida fipronil, pimetrozin, BPMC dan imidakloprid lebih rendah dan berbeda nyata dengan kontrol, sedangkan pada perlakuan rinaksipir dan dinotefuran tidak berbeda dengan kontrol (Tabel 1).

Pada pengamatan 5 HSA populasi laba-laba predator pada perlakuan insektisida rinaksipir, fipronil, dan imidakloprid lebih rendah dan berbeda nyata dengan kontrol, sedangkan pada perlakuan dinotefuran, pimetrozin, BPMC tidak berbeda dengan kontrol. Pada 7 HSA populasi laba-laba pada semua perlakuan insektisida lebih rendah dan berbeda nyata dengan kontrol, kecuali perlakuan rinaksipir tidak berbeda dengan kontrol. Pada 10 HSA populasi laba-laba pada semua perlakuan insektisida tidak berbeda nyata dengan kontrol, kecuali perlakuan pimetrozin berbeda dengan kontrol (Tabel 1). 
Tabel 1. Keberadaan laba-laba predator setelah aplikasi insektisida.

\begin{tabular}{|c|c|c|c|c|c|c|c|c|}
\hline \multirow{2}{*}{$\begin{array}{l}\text { Perlakuan } \\
\text { insektisida }\end{array}$} & \multirow{2}{*}{ Dosis } & \multicolumn{4}{|c|}{ Laba-laba predator (ekor/4 ayunan sweeping) } & \multicolumn{3}{|c|}{ setelah apliksi insektisida (HSA) } \\
\hline & & 1 & 3 & 5 & 7 & 10 & 15 & 21 \\
\hline Rinaksipir & $500 \mathrm{cc}$ & $5,25 \mathrm{ab}$ & $10,25 \mathrm{ab}$ & 8,00 a & $5,00 \mathrm{ab}$ & $5,25 \mathrm{ab}$ & $3,00 \mathrm{~b}$ & $10,50 \mathrm{a}$ \\
\hline Fipronil & $24 \mathrm{~g}$ & $6,00 \mathrm{ab}$ & $7,00 \mathrm{bc}$ & $5,75 \mathrm{ab}$ & $4,50 \mathrm{~b}$ & $4,75 \mathrm{ab}$ & $3,75 \mathrm{ab}$ & $10,75 \mathrm{a}$ \\
\hline Dinotefuran & $500 \mathrm{~g}$ & $4,00 \mathrm{~b}$ & $8,25 \mathrm{ab}$ & $4,00 \mathrm{~b}$ & $3,75 \mathrm{~b}$ & $5,50 \mathrm{ab}$ & $2,75 \mathrm{~b}$ & $10,00 \mathrm{a}$ \\
\hline Pimetrozin & $500 \mathrm{~g}$ & $4,00 \mathrm{~b}$ & $4,75 \mathrm{c}$ & $4,25 \mathrm{~b}$ & $3,75 \mathrm{~b}$ & $3,00 \mathrm{~b}$ & $2,50 \mathrm{~b}$ & 8,25 a \\
\hline BPMC & $1 \mathrm{lt}$ & $5,00 \mathrm{ab}$ & $6,25 \mathrm{bc}$ & $4,25 \mathrm{~b}$ & $4,25 \mathrm{~b}$ & $5,50 \mathrm{ab}$ & $3,25 \mathrm{ab}$ & $10,00 \mathrm{a}$ \\
\hline Imidakloprid & $30 \mathrm{~g}$ & $4,25 \mathrm{~b}$ & $6,75 \mathrm{bc}$ & $5,25 \mathrm{ab}$ & $4,25 \mathrm{~b}$ & $5,00 \mathrm{ab}$ & $2,00 \mathrm{~b}$ & $9,75 \mathrm{a}$ \\
\hline Kontrol & & 7,75 a & $12,50 \mathrm{a}$ & $7,50 \mathrm{a}$ & $6,25 \mathrm{a}$ & $7,25 \mathrm{a}$ & $6,50 \mathrm{a}$ & $13,00 \mathrm{a}$ \\
\hline
\end{tabular}

Angka rata-rata pada satu kolom yang diikuti huruf yang sama tidak menunjukkan perbedaan yang nyata pada taraf $5 \%$ uji DMRT.

Pada 15 HSA populasi laba-laba pada semua perlakuan insektisida lebih rendah dan berbeda nyata dengan kontrol, kecuali perlakuan fipronil dan BPMC tidak berbeda dengan kontrol. Pada 21 HSA populasi laba-laba pada semua perlakuan insektisida tidak berbeda nyata dengan kontrol (Tabel 1). Keberadaan laba-laba di pertanaman yang diaplikasi insektisida lebih rendah dibanding dengan yang tidak diaplikasi insektisida, walaupun di beberapa pengamatan populasi laba-laba tidak berbeda dengan kontrol. Secara keseluruhan perlakuan rinaksipir dan fipronil relatif aman terhadap laba-laba. Hal yang sama terjadi pada penelitian Rodrigues et al. (2013) bahwa aplikasi insektisida dapat menurunkan populasi laba-laba, namun demikian keberadaan laba-laba berbeda pada setiap tempat dan setiap waktu pengamatan.

Aplikasi insektisida selain dapat menurunkan populasi hama, juga memberikan pengaruh negatif secara langsung maupun tidak langsung terhadap keberadaan musuh alami. Sebagaimana halnya insektisida dinotefuran, pimetrozin, imidakloprid dan BPMC menurunkan populasi laba-laba, sedangkan insektisida rinaksipir dan fipronil sedikit menurunkan populasi laba-laba. Di Brazil Selatan pemakaian insektisida lamdasihalotrin bereaksi cepat menurunkan populasi musuh alami laba-laba Phytoseiidae dan Araneidae, padahal dua famili laba-laba ini dianggap musuh alami penting untuk pengelolaan hama di daerah tersebut (Fritz et al., 2013). Kehadiran laba-laba sangat diharapkan untuk menurunkan populasi hama wereng coklat. Labalaba $P$. pseudoannulata dan laba-laba $T$. maxillosa berpotensi tinggi menekan populasi wereng coklat pada tanaman padi dengan kemampuan memangsa masing masing 4,05 dan 3,10 ekor/hari (Marheni, 2004).

Tabel 2. Keberadaan T. rowani setelah aplikasi insektisida.

\begin{tabular}{|c|c|c|c|c|c|c|c|c|}
\hline \multirow{2}{*}{$\begin{array}{l}\text { Perlakuan } \\
\text { insektisida }\end{array}$} & \multirow{2}{*}{ Dosis } & \multicolumn{7}{|c|}{ T. rowani (ekor/4 ayunan sweeping) setelah aplikssi insektisida (HSA) } \\
\hline & & 1 & 3 & 5 & 7 & 10 & 15 & 21 \\
\hline Rinaksipir & $500 \mathrm{cc}$ & $1,75 \mathrm{~b}$ & $0,50 \mathrm{~b}$ & $2,00 \mathrm{~b}$ & $4,25 \mathrm{a}$ & $1,50 \mathrm{~b}$ & $8,00 \mathrm{ab}$ & $5,00 \mathrm{ab}$ \\
\hline Fipronil & $24 \mathrm{~g}$ & $1,00 \mathrm{~b}$ & $1,25 \mathrm{~b}$ & $0,75 \mathrm{bc}$ & $2,50 \mathrm{a}$ & $1,75 \mathrm{~b}$ & $4,25 \mathrm{~b}$ & $4,00 \mathrm{bc}$ \\
\hline Dinotefuran & $500 \mathrm{~g}$ & $0,25 \mathrm{~b}$ & $0,50 \mathrm{~b}$ & $0,50 \mathrm{c}$ & 3,25 a & $1,25 \mathrm{~b}$ & $4,50 \mathrm{~b}$ & $2,25 \mathrm{c}$ \\
\hline Pimetrozin & $500 \mathrm{~g}$ & $0,50 \mathrm{~b}$ & $1,00 \mathrm{~b}$ & $1,25 \mathrm{bc}$ & $2,25 \mathrm{a}$ & $1,75 \mathrm{~b}$ & $6,50 \mathrm{ab}$ & $4,00 \mathrm{bc}$ \\
\hline BPMC & $1 \mathrm{lt}$ & $0,75 \mathrm{~b}$ & $1,00 \mathrm{~b}$ & $1,25 \mathrm{bc}$ & $2,50 \mathrm{a}$ & $2,00 \mathrm{~b}$ & $4,75 \mathrm{~b}$ & $5,00 \mathrm{ab}$ \\
\hline Imidakloprid & $30 \mathrm{~g}$ & $0,75 \mathrm{~b}$ & $1,00 \mathrm{~b}$ & $1,25 \mathrm{bc}$ & $2,50 \mathrm{a}$ & $2,25 \mathrm{~b}$ & $4,00 \mathrm{~b}$ & $3,00 \quad \mathrm{c}$ \\
\hline Kontrol & & $3,50 \mathrm{a}$ & $3,75 \mathrm{a}$ & $3,25 \mathrm{a}$ & $3,75 \mathrm{a}$ & $4,00 \mathrm{a}$ & $9,25 \mathrm{a}$ & $7,00 \mathrm{a}$ \\
\hline
\end{tabular}

Angka rata-rata pada satu kolom yang diikuti huruf yang sama tidak menunjukkan perbedaan yang nyata pada taraf 5\% uji DMRT.

Pengaruh insektisida terhadap T. rowani dapat dilihat dari pengamatan 1,3,5, dan 10 HSA yang menunjukkan populasi pada semua perlakuan insektisida lebih rendah dan berbeda nyata dibanding kontrol. Pada 7 HSA populasi T. rowani pada semua perlakuan insektisida tidak berbeda nyata dibanding kontrol. Pada 15 HSA populasi $T$. rowani pada semua perlakuan insektisida lebih rendah dan berbeda nyata dibanding kontrol, kecuali pada perlakuan insektisida rinaksipir dan 
pimetrozin tidak berbeda dibanding kontrol. Pada 21 HSA populasi T. rowani pada semua perlakuan insektisida lebih rendah dan berbeda nyata dibanding kontrol, kecuali pada perlakuan insektisida rinaksipir dan BPMC tidak berbeda dibanding kontrol (Tabel 2).

Pengaruh insektisida terhadap T. schoenobii pada pengamatan $1,3,5,7$, dan 21 HSA pada semua perlakuan insektisida tidak erbeda nyata dibanding kontrol. Pengaruh insektisida baru terlihat pada 10
HSA dimana populasi T. schoenobii pada semua perlakuan insektisida lebih rendah dan berbeda nyata dibanding kontrol, kecuali pada perlakuan insektisida rinaksipir dan imidakloprid tidak berbeda nyata dibanding kontrol. Pada 15 HSA populasi $T$. schoenobii pada semua perlakuan insektisida tidak berbeda nyata dibanding kontrol, kecuali pada perlakuan insektisida pimetrozin dan imidakloprid lebih rendah dan berbeda nyata dibanding kontrol (Tabel 3).

Tabel 3. Keberadaan T. schoenobii setelah aplikasi insektisida.

\begin{tabular}{|c|c|c|c|c|c|c|c|c|c|}
\hline \multirow{2}{*}{$\begin{array}{l}\text { Perlakuan } \\
\text { insektisida }\end{array}$} & \multirow{2}{*}{ Dosis } & \multicolumn{8}{|c|}{ T. schoenobii (ekor/4 ayunan sweeping) setelah aplikssi insektisida (HSA) } \\
\hline & & 1 & 3 & 5 & & 7 & 10 & 15 & 21 \\
\hline Rinaksipir & $500 \mathrm{cc}$ & $0,50 \mathrm{a}$ & 0 & 0 & $\mathrm{a}$ & $1,50 \mathrm{a}$ & $2,50 \mathrm{ab}$ & $2,25 \mathrm{ab}$ & 4,25 \\
\hline Fipronil & $24 \mathrm{~g}$ & 0,25 a & $0,25 \mathrm{a}$ & 0 & a & $1,00 \mathrm{a}$ & $1,25 \mathrm{bc}$ & $2,50 \mathrm{ab}$ & 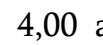 \\
\hline Dinotefuran & $500 \mathrm{~g}$ & $0,25 \mathrm{a}$ & $0,25 \mathrm{a}$ & 0,25 & a & $1,50 \mathrm{a}$ & $1,00 \quad \mathrm{c}$ & $2,50 \mathrm{ab}$ & $2,50 a$ \\
\hline Pimetrozin & $500 \mathrm{~g}$ & $0,25 \mathrm{a}$ & $0,25 \mathrm{a}$ & 0 & $\mathrm{a}$ & $2,00 \mathrm{a}$ & $0,750 \mathrm{c}$ & $0,75 \mathrm{~b}$ & $4,00 \mathrm{a}$ \\
\hline BPMC & $1 \mathrm{lt}$ & $0,25 \mathrm{a}$ & $0 \quad \mathrm{a}$ & 0,25 & $\mathrm{a}$ & $1,75 \mathrm{a}$ & $1,00 \quad \mathrm{c}$ & $2,50 \mathrm{ab}$ & 2,00 \\
\hline Imidakloprid & $30 \mathrm{~g}$ & $0,00 \mathrm{a}$ & $0,25 \mathrm{a}$ & 0 & $\mathrm{a}$ & $2,25 \mathrm{a}$ & $1,50 \mathrm{abc}$ & $1,50 \mathrm{~b}$ & 3,25 \\
\hline Kontrol & & $1,50 \mathrm{a}$ & $1,00 \mathrm{a}$ & 1,00 & $\mathrm{a}$ & $2,75 \mathrm{a}$ & $2,75 \mathrm{a}$ & $4,00 \mathrm{a}$ & $4,00 \mathrm{a}$ \\
\hline
\end{tabular}

Angka rata-rata pada satu kolom yang diikuti huruf yang sama tidak menunjukkan perbedaan yang nyata pada taraf $5 \%$ uji DMRT.

Insektisida rinaksipir, fipronil, dinotefuran, pimetrozin, imidakloprid, dan BPMC menekan sangat tinggi terhadap $\mathrm{T}$. rowani, sedangkan terhadap T. schoenobii sangat rendah terutama insektisida rinaksipir. Insektisida imidakloprid merupakan racun kontak tekanannya sangat kuat terhadap T. rowani dapat membunuh langsung dalam beberapa jam setelah aplikasi yang mengenai target atau habitatnya. Demikian juga residunya masih mampu membunuh hama dan musuh alaminya, walaupun kemanjurannya tergantung dosis dan cara aplikasinya (http://www.ipm.ucdavis.edu). Kinerja parasitoid telur penggerek sangat baik, karena di lapangan parasitoid ini berperan menurunkan penggerek padi, sebagaimana ditunjukkan dengan parasitasi telur penggerek padi akibat $T$. rowani, Telenomus dingus, T. schoenobii dan Trichogramma mencapai $44.4 \%$ di musim kemarau dan $46,8 \%$ di musim hujan (Baehaki, 2010). Parasitasi Trichogramma sp., Telonomus sp. dan Tetrastichus sp. pada tanaman tanpa insektisida mencapai $74,6 \%$, sedangkan pada pertanaman yang diaplikasi insektisida (metil parathion saat pesemaian, endosulfan saat vegetatif dan forat saat generatif) parasitasinya hanya $44,1 \%$ (Chakraborty, 2010). Di Bengal Barat-India, parasitasi dari Trichogramma sp., Telonomus sp., dan Tetrastichus sp. berturut-turut mencapai 6,12\%, 9.53\% and 48,44\% (Chakraborty, 2012).

Pengaruh insektisida rinaksipir, fipronil, dinotefuran, pimetrozin, imidakloprid, dan BPMC terhadap Oligosita sp. pada 1, 3, 5 HSA tidak berbeda nyata dibanding kontrol. Pada 7 HSA populasi Oligosita sp. pada semua perlakuan insektisida lebih rendah dan berbeda nyata dibanding kontrol, kecuali pada perlakuan insektisida BPMC dan imidakloprid tidak berbeda nyata dibanding kontrol (Tabel 4). Pada 10 HSA populasi Oligosita sp. pada semua perlakuan insektisida lebih rendah dan berbeda nyata dibanding kontrol. Pada 15 HSA populasi Oligosita sp. pada semua perlakuan insektisida lebih rendah dan berbeda nyata dibanding kontrol, kecuali pada perlakuan insektisida rinaksipir dan imidakloprid tidak berbeda nyata dibanding kontrol. Pada 21 HSA populasi Oligosita sp. pada perlakuan insektisida rinaksipir, dinotefuran, dan imidakloprid lebih rendah dan berbeda nyata dibanding kontrol, sedangkan pada perlakuan insektisida fipronil, pimetrozin, dan BPMC tidak berbeda nyata dibanding kontrol. 
Tabel 4. Keberadaan Oligosita sp. setelah aplikasi insektisida.

\begin{tabular}{|c|c|c|c|c|c|c|c|c|}
\hline \multirow{2}{*}{$\begin{array}{l}\text { Perlakuan } \\
\text { insektisida }\end{array}$} & \multirow{2}{*}{ Dosis } & \multicolumn{7}{|c|}{ Oligosita sp. (ekor/4 ayunan sweeping) setelah aplikssi insektisida (HSA) } \\
\hline & & 1 & 3 & 5 & 7 & 10 & 15 & 21 \\
\hline Rinaksipir & $500 \mathrm{cc}$ & $0,25 \mathrm{a}$ & 0 & $1,25 \mathrm{a}$ & $14,25 \mathrm{bc}$ & $7,25 \mathrm{bc}$ & $12,75 \mathrm{ab}$ & $8,75 \mathrm{~b}$ \\
\hline Fipronil & $24 \mathrm{~g}$ & 0,25 a & 0 & $0,50 \mathrm{a}$ & $12,75 \mathrm{bc}$ & $4,50 \mathrm{~d}$ & $7,75 \mathrm{~b}$ & $12,25 \mathrm{ab}$ \\
\hline Dinotefuran & $500 \mathrm{~g}$ & 0,25 a & 0 & $0,25 \mathrm{a}$ & $8,25 \mathrm{c}$ & $4,75 \mathrm{~cd}$ & $8,25 \mathrm{~b}$ & $7,00 \mathrm{~b}$ \\
\hline Pimetrozin & $500 \mathrm{~g}$ & 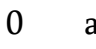 & 0 & $0,25 \mathrm{a}$ & $7,50 \mathrm{c}$ & 5,50 bcd & $8,75 \mathrm{~b}$ & $10,75 \mathrm{ab}$ \\
\hline BPMC & $1 \mathrm{lt}$ & $0,25 \mathrm{a}$ & 0 & $0,50 \mathrm{a}$ & $16,25 \mathrm{abc}$ & $8,00 \mathrm{~b}$ & $10,75 \mathrm{~b}$ & $15,75 \mathrm{ab}$ \\
\hline Imidakloprid & $30 \mathrm{~g}$ & $0 \quad \mathrm{a}$ & 0 & $0,75 \mathrm{a}$ & $22,50 \mathrm{ab}$ & $6,25 \mathrm{bcd}$ & $15,25 \mathrm{ab}$ & $5,50 \mathrm{~b}$ \\
\hline Kontrol & & $0,25 \mathrm{a}$ & 0 & $1,75 \mathrm{a}$ & $26,25 \mathrm{a}$ & $11,75 \mathrm{a}$ & $20,00 \mathrm{a}$ & $21,25 \mathrm{a}$ \\
\hline
\end{tabular}

Angka rata-rata pada satu kolom yang diikuti huruf yang sama tidak menunjukkan perbedaan yang nyata pada taraf $5 \%$ uji DMRT.

Pada 1, 3, 5 HSA populasi Anagrus sp. pada semua perlakuan insektisida tidak berbeda nyata dibanding kontrol. Pada 7 dan 10 HSA populasi Anagrus sp. pada semua perlakuan insektisida lebih rendah dan berbeda nyata dibanding kontrol. Pada 15 HSA populasi Anagrus sp pada semua perlakuan insektisida lebih rendah dan berbeda nyata dibanding kontrol, kecuali pada perlakuan insektisida rinaksipir dan imidakloprid tidak berbeda nyata dibanding kontrol (Tabel 5). Pada 21 HSA populasi Anagrus sp. pada semua perlakuan insektisida lebih rendah dan berbeda nyata dibanding kontrol, kecuali pada perlakuan insektisida fipronil dan BPMC tidak berbeda nyata dibanding kontrol.

Tabel 5. Keberadaan Anagrus sp. setelah aplikasi insektisida.

\begin{tabular}{|c|c|c|c|c|c|c|c|c|c|}
\hline \multirow{2}{*}{$\begin{array}{l}\text { Perlakuan } \\
\text { insektisida }\end{array}$} & \multirow[t]{2}{*}{ Dosis } & \multicolumn{8}{|c|}{ Anagrus sp. (ekor/4 ayunan sweeping) setelah aplikssi insektisida (HSA) } \\
\hline & & 1 & 3 & 5 & 7 & & 10 & 15 & 21 \\
\hline Rinaksipir & $500 \mathrm{cc}$ & 0 & 0 & $0,25 \mathrm{a}$ & 0,75 & $\mathrm{~b}$ & 0,25 & $5,50 \mathrm{ab}$ & $1,50 \mathrm{~b}$ \\
\hline Fipronil & $24 \mathrm{~g}$ & 0 & 0 & $0,50 \mathrm{a}$ & 1,25 & $\mathrm{~b}$ & 0,00 & $3,50 \mathrm{~b}$ & $2,50 \mathrm{ab}$ \\
\hline Dinotefuran & $500 \mathrm{~g}$ & 0 & 0 & $0,00 \mathrm{a}$ & 1,25 & $\mathrm{~b}$ & 0,50 & $4,75 \mathrm{~b}$ & $1,75 \mathrm{~b}$ \\
\hline Pimetrozin & $500 \mathrm{~g}$ & 0 & 0 & $0,50 \mathrm{a}$ & 0,50 & $\mathrm{~b}$ & 0,00 & $3,25 \mathrm{~b}$ & $1,75 \mathrm{~b}$ \\
\hline BPMC & $1 \mathrm{lt}$ & 0 & 0 & $0,25 \mathrm{a}$ & 1,00 & $\mathrm{~b}$ & 0,50 & $4,50 \mathrm{~b}$ & $2,50 \mathrm{ab}$ \\
\hline Imidakloprid & $30 \mathrm{~g}$ & 0 & 0 & $0,50 \mathrm{a}$ & 1,00 & b & 0,00 & $7,50 \mathrm{ab}$ & $1,25 \mathrm{~b}$ \\
\hline Kontrol & & 0 & 0 & $0,25 \mathrm{a}$ & 2,25 & & $1,25 \mathrm{a}$ & 10,75 a & $4,00 \mathrm{a}$ \\
\hline
\end{tabular}

Angka rata-rata pada satu kolom yang diikuti huruf yang sama tidak menunjukkan perbedaan yang nyata pada taraf $5 \%$ uji DMRT.

Populasi Oligosita sp. dan Anagrus sp. sebagai parasitoid telur hama wereng coklat dan wereng punggung putih pada pengamatan $1,3,5$ HSA sangat rendah, sehingga kinerja insektisida baru terlihat pada 7, 10, 15, dan 21 HSA dengan hasil bahwa semua insektisida berpengaruh negatif terhadap kedua parasitoid tersebut. Insektisida yang agak menekan populasi parasitoid tersebut adalah rinaksipir, fipronil, BPMC dan imidakloprid. Hasil penelitian ini berbeda dengan Wang et al. (2008) yang menunjukkan bahwa klorpirifos memiliki toksisitas tertinggi untuk Anagrus nilaparvatae dan imidakloprid adalah insektisida yang paling beracun kedua, sementara insect growth regulators (IGR) memiliki toksisitas terendah. Toksisitas oral diklorvos terhadap A. nilaparvatae adalah yang paling beracun dengan angka kematian 100\% hanya dalam waktu 2 jam setelah perlakuan. Isoprokarb, imidakloprid, dan tiametoksam adalah insektisida yang paling beracun kedua dan membunuh semua A. nilaparvatae dalam waktu 4 jam. Toksisitas residu menunjukkan bahwa imidakloprid adalah insektisida persisten masih mampu meracuni $A$. nilaparvatae dengan kematian mencapai 80,7\% pada 7 hari setelah perlakuan, demikian juga thiametoksam, triazofos, dan fipronil juga memiliki toksisitas residu pada 7 hari setelah perlakuan menimbulkan kematian berturut-turut 66,8\%; 54,6\% dan 50,0\% (Wang et al., 2008).

Pada 1 HSA populasi chironomid pada semua perlakuan insektisida lebih rendah dan berbeda nyata dibanding kontrol, kecuali pada 
perlakuan insektisida rinaksipir dan fipronil tidak berbeda nyata dibanding kontrol. Pada 3 HSA populasi chironomid pada semua perlakuan insektisida tidak berbeda nyata dibanding kontrol, kecuali pada perlakuan insektisida pimetrozin berbeda nyata dibanding kontrol. Pada 5 dan 10 HSA populasi chironomid pada semua perlakuan insektisida lebih rendah dan berbeda nyata dibanding kontrol (Tabel 6). Pada 7 HSA populasi chironomid pada semua perlakuan insektisida lebih rendah dan berbeda nyata dibanding kontrol, kecuali pada perlakuan insektisida fipronil dan BPMC tidak berbeda nyata dibanding kontrol. Pada 15 HSA populasi chironomid pada semua perlakuan insektisida tidak berbeda nyata dibanding kontrol dan pada 21 HSA populasi chironomid pada semua perlakuan insektisida lebih rendah dan berbeda nyata dibanding kontrol, kecuali pada perlakuan insektisida BPMC tidak berbeda nyata dibanding kontrol.

Tabel 6. Keberadaan chironomid setelah aplikasi insektisida.

\begin{tabular}{llcrrrrrr}
\hline \multirow{2}{*}{$\begin{array}{l}\text { Perlakuan } \\
\text { insektisida }\end{array}$} & \multirow{2}{*}{ Dosis } & \multicolumn{6}{c}{ Chironomid (ekor/4 ayunan sweeping) setelah aplikssi insektisida (HSA) } \\
\cline { 3 - 8 } & & 1 & 3 & 5 & 7 & 10 & 15 & 21 \\
\hline Rinaksipir & $500 \mathrm{cc}$ & $184,50 \mathrm{ab}$ & $73,50 \mathrm{a}$ & $18,50 \mathrm{~b}$ & $33,50 \mathrm{~b}$ & $19,75 \mathrm{bc}$ & $15,50 \mathrm{a}$ & $20,75 \mathrm{~b}$ \\
Fipronil & $24 \mathrm{~g}$ & $178,25 \mathrm{ab}$ & $65,25 \mathrm{a}$ & $35,00 \mathrm{~b}$ & $54,00 \mathrm{ab}$ & $17,75 \mathrm{bcd}$ & $12,00 \mathrm{a}$ & $25,25 \mathrm{~b}$ \\
Dinotefuran & $500 \mathrm{~g}$ & $116,50 \mathrm{~cd}$ & $42,00 \mathrm{a}$ & $27,75 \mathrm{~b}$ & $36,50 \mathrm{~b}$ & $9,25 \mathrm{c}$ & $7,75 \mathrm{a}$ & $24,25 \mathrm{~b}$ \\
Pimetrozin & $500 \mathrm{~g}$ & $75,25 \mathrm{~d}$ & $33,25 \mathrm{~b}$ & $33,00 \mathrm{~b}$ & $28,75 \mathrm{~b}$ & $12,25 \mathrm{~cd}$ & $10,75 \mathrm{a}$ & $23,50 \mathrm{~b}$ \\
BPMC & $1 \mathrm{lt}$ & $130,50 \mathrm{bc}$ & $67,25 \mathrm{a}$ & $30,75 \mathrm{~b}$ & $47,25 \mathrm{ab}$ & $18,75 \mathrm{bc}$ & $9,00 \mathrm{a}$ & $36,75 \mathrm{ab}$ \\
Imidakloprid & $30 \mathrm{~g}$ & $138,00 \mathrm{bc}$ & $47,00 \mathrm{a}$ & $34,50 \mathrm{~b}$ & $30,50 \mathrm{~b}$ & $25,00 \mathrm{~b}$ & $9,50 \mathrm{a}$ & $23,25 \mathrm{~b}$ \\
Kontrol & & $222,75 \mathrm{a}$ & $79,75 \mathrm{a}$ & $79,00 \mathrm{a}$ & $69,75 \mathrm{a}$ & $36,75 \mathrm{a}$ & $11,00 \mathrm{a}$ & $48,25 \mathrm{a}$ \\
\hline
\end{tabular}

Angka rata-rata pada satu kolom yang diikuti huruf yang sama tidak menunjukkan perbedaan yang nyata pada taraf $5 \%$ uji DMRT.

Semua pestisida yang diuji menurunkan populasi chironomid, terkecuali insektisida fipronil dan BPMC yang agak menekan chironomid. Hal yang serupa dilaporkan Al-Shami et al. (2010) bahwa karbofuran lebih beracun terhadap chironomid dibanding fipronil, namun demikian pestisida yang digunakan pada tanaman padi memiliki efek negatif terhadap populasi Chironomidae yang mana kepadatan larva Chironomidae berbeda antara perlakuan fipronil dan pertanaman kontrol (Marchiori, 2012).

Penggunaan insektisida pada tanaman padi harus hati-hati karena dapat menurunkan populasi serangga non-target seperti predator, parasitod dan serangga netral yang sangat dibutuhkan keberadaannya dalam satu ekosistem. Keberadaan serangga netral chironomid erat kaitannya dengan rantai makanan karena serangga netral masuk dalam satu level tropic sebagai makanan predator diantaranya laba-laba, Coccinellidae, Staphylinidae, Carabidae, dan Libellulidae.

\section{Kecepatan Rekolonisasi Musuh Alami dan Serangga Netral Serta Daya Hambat Insektisida}

Kecepatan rekolonisasi laba-laba pada rinaksipir, fipronil, dan BPMC terjadi pada $1 \mathrm{HSA}$, pada dinotefuran 3 HSA, pada imidakloprid 5 HSA dan pada pimetrozin 21 HSA. Kecepatan rekolonisasi T. rowani pada semua perlakuan insektisida terjadi pada 7 HSA, rekolonisasi T. schoenobii dan Oligosita sp. pada semua perlakuan insektisida terjadi pada 1 HSA, kecepatan rekolonisasi Anagrus sp. pada semua perlakuan insektisida terjadi pada 5 HSA. Kecepatan rekolonisasi chironimid pada rinaksipir dan fipronil pada 1 HSA, sedangkan pada dinotefuran, imidakloprid, dan BPMC pada 3 HSA, serta pada perlakuan pimetrozin pada 15 HSA.

Indeks hambatan rekolonisasi (IHR) labalaba adalah 14,29\% (sangat ringan) oleh perlakuan insektisida rinaksipir, IHR sebesar $28,57 \%$ (ringan) diberikan oleh fipronil, IHR berat $(57,14 \%)$ diberikan oleh dinotefuran, imidakloprid dan BPMC. Di lain pihak IHR laba-laba sebesar $85,71 \%$ (sangat berat) oleh insektisida pimetrozin (Tabel 7). $T$. rowani terhambat berat oleh perlakuan insektisida rinaksipir, pimetrozin dan BPMC, di lain pihak T. rowani mendapat hambatan sangat berat dengan indeks rekolonisasi sebesar $85,71 \%$ oleh insektisida fipronil, dinotefuran, dan imidakloprid. Di Thailand insektisida fipronil tidak berbahaya untuk laba-laba dan tidak berbahaya-cukup berbahaya bagi parasitoid telur wereng coklat (Oligosita sp.), imidakloprid tidak berbahaya untuk laba-laba dan sedikit berbahaya bagi Oligosita sp., 
selain itu ditemukan juga bahwa fipronil tidak bisa mengendalikan wereng coklat, tapi imidakloprid masih menunjukkan hasil yang baik (Ruay-aree, 2002). Turchen et al. (2016) melaporkan bahwa insektisida imidakloprid menunjukkan aktivitas mematikan akut tinggi terhadap parasitoid Telenomus podisi dalam kontak dengan residu insektisida kering, hal itu menunjukkan efek negatif yang kuat dari imidakloprid.

Perlakuan insektisida rinaksipir, fipronil, dinotefuran, imidakloprid, dan BPMC memberikan hambatan sangat ringan dengan IHR antara 0$14,29 \%$ terhadap T. schoenobii, sedangkan pimetrozin memberikan hambatan ringan dengan IHR sebesar 28,57\%. Parasitoid Oligosita sp. mendapat hambatan ringan dengan IHR antara
28,57-42,86\% oleh perlakuan insektisida rinaksipir, fipronil, pimetrozin, BPMC dan imidakloprid, sedangkan insektisida dinotefuran memberikan hambatan berat $(57,14 \%)$ terhadap rekolonisasai Oligosita sp. Rekolonisasi Anagrus sp. mendapat hambatan ringan $(42,86 \%)$ oleh perlakuan insektisida rinaksipir, fipronil, BPMC dan imidakloprid. Di lain pihak insektisida dinotefuran dan pimetrozin memberikan hambatan berat (57,14\%) terhadap rekolonisasai Anagrus sp. Chironomid mendapat hambatan ringan sebesar $42,86 \%$ oleh perlakuan insektisida fipronil dan BPMC, hambatan berat oleh rinaksipir, dinotefuran, dan imidakloprid, serta terhambat sangat berat oleh insektisida pimetrozin (Tabel 7).

Tabel 7. Daya hambat insektisida terhadap rekolonisasi musuh alami dan serangga netral.

\begin{tabular}{lrrrrrr}
\hline \multirow{2}{*}{ Insektisida } & \multicolumn{5}{c}{ Hambatan rekolonisasi musuh alami dan serangga netral (\%)* } \\
\cline { 2 - 7 } & Laba-laba & T. rowani & T. schoenobii & Oligosita sp. & Anagrus sp. & Chironomid \\
\hline Rinaksipir & 14,29 & 57,14 & 0 & 42,86 & 42,86 & 57,14 \\
Fipronil & 28,57 & 85,71 & 14,29 & 42,86 & 42,86 & 42,86 \\
Dinotefuran & 57,14 & 85,71 & 14,29 & 57,14 & 57,14 & 71,43 \\
Pimetrozin & 85,71 & 71,43 & 28,57 & 42,86 & 57,14 & 85,71 \\
BPMC & 57,14 & 71,43 & 14,29 & 28,57 & 42,86 & 42,86 \\
Imidakloprid & 57,14 & 85,71 & 14,29 & 28,57 & 42,86 & 71,43 \\
Kontrol & 0 & 0 & 0 & 0 & 0 & 0 \\
\hline
\end{tabular}

${ }^{*}$ Kriteria hambatan rekolonisasi musuh alami adalah: $0 \%=$ tidak ada hambatan, $0<\mathrm{x} \leq 25 \%$ = hambatan sangat ringan, $25<\mathrm{x} \leq 50$ = hambatan ringan, $50<\mathrm{x} \leq 75$ = hambatan berat, $75<\mathrm{x} \leq 100$ = hambatan sangat berat.

Hasil tersebut di atas menunjukkan bahwa setiap bahan aktif dari golongan yang sama atau golongan berbeda akan memberikan pengaruh berbeda terhadap musuh alami dan serangga netral. Bahan aktif insektisida dari golongan yang sama maupun dari golongan berbeda sebagaimana halnya rinaksipir sama dengan klorantraniliprol (golongan antranilik diamid), fipronil (pirazol), dinotefuran (neonikotinoid), pimetrozin (piridin azometin), dan imidakloprid (neonikotinoid), serta generasi lama BPMC (karbamat) memberikan pengaruh yang berbeda tergantung musuh alami dari predator dan parasitoid atau jenis serangga netral.

Insektisida yang dipandang rendah toksisitasnya adalah rinaksipir dengan indek hambatan sangat ringan terhadap laba-laba, tidak ada hambatan terhadap T. Schoenobii, hambatan ringan terhadap Oligosita sp. dan Anagrus sp., sedangkan indeks hambatan berat terhadap $T$. rowani dan chironomid. Insektisida rinaksipir diklasifikasikan sebagai insektisida mengurangi risiko, memiliki toksisitas rendah dan kompatibel dengan pengendalian hayati (Roubos, 2014). Di lain pihak insektisida rinaksipir menunjukkan toksisitas rendah terhadap lebah madu pada tingkat aplikasi 60 g rinaksipir per ha sehingga formulasi rinaksipir sangat baik diikutsertakan pada pengendalian hama terpadu (PHT) untuk program melestarikan serangga penyerbuk lebah madu (Dinter et al, 2009).

Di lapangan kurangnya populasi predator dan parasitoid tidak saja akibat langsung terkena insektisida, namun dapat juga terjadi akibat tidak langsung disebabkan kurangnya makanan predator dan parasitoid akibat hama banyak yang mati karena insektisida. Populasi hama akan menurun karena terbunuh oleh insektisida, mengakibatkan populasi predator akan menurun karena kurangnya makanan (Desneux et al., 2007). Kurangnya makanan parasitoid dapat juga diakibatkan pengaruh negatif dari insektisida neonicotinoid secara tidak langsung yaitu pada semprotan daun atau diberikan dalam butiran dapat menurunkan tingkat populasi hama 
yang menyebabkan tidak ada kecukupan mangsa bagi parasitoid untuk berkembang dan mempertahankan populasinya (Cloyd \& Bethke, 2011). Insektisida thiacloprid dapat menurunkan hama dan menyebabkan perubahan perilaku predator Macrolophus pygmaeus seperti peningkatan istirahat dan waktu bersolek (resting and preening time), sedangkan rinaksipir mengakibatkan penurunan hama, tetapi tidak merubah perilaku predator. Insekktisida thiacloprid secara signifikan mengurangi tingkat predasi $\mathrm{M}$. pygmaeus, sedangkan rinaksipir tidak berpengaruh signifikan terhadap tingkat predasi (Martinou et al., 2014). Dari hasil penelitian dan keseluruhan pembahasan menunjukkan bahwa enggunaan insektisida untuk mengendalikan hama dapat memberikan pengaruh samping yang menurunkan populasi musuh alami atau serangga netral. Dampak dari pengendalian hama terhadap musuh alami harus diminimalkan dengan mencari ciri-ciri yang berhubungan dengan selektivitas pestisida sehingga kekuatan atau kelemahan dari penggunaan pestisida harus diidentifikasi sebelum digunakan (Tores, 2012).

\section{SIMPULAN}

1. Bahan aktif insektisida dari golongan yang sama maupun dari golongan berbeda memberikan pengaruh yang berbeda tergantung musuh alami dari predator dan parasitoid atau jenis serangga netral.

2. Insektisida rinaksipir dan fipronil relatif aman terhadap laba-laba dengan nilai indeks hambatan rekolonisasi (IHR) kedua insektisida tersebut sangat ringan dan ringan dengan kecepatan rekolonisasi laba-laba pada 1 HSA.

3. Insektisida rinaksipir, fipronil, dinotefuran, pimetrozin, imidakloprid, dan BPMC menekan sangat tinggi terhadap T. rowani, dengan IHR berat sampai sangat berat dan rekolonisasi $T$. rowani pada semua perlakuan insektisida dinilai lambat yaitu pada 7 HSA.

4. Semua insektisida menekan sangat rendah terhadap T. schoenobii terutama insektisida rinaksipir dengan nilai IHR dari tidak ada hambatan sampai hambatan ringan dan kecepatan rekolonisasi parasitoid tersebut terjadi pada 1 HSA.

5. Insektisida yang agak menekan populasi parasitoid Oligosita sp. dan Anagrus sp. adalah rinaksipir, fipronil, imidakloprid, dan BPMC dengan nilai IHR ringan dengan kecepatan rekolonisasi Oligosita sp. pada 1 HSA dan kecepatan rekolonisasi Anagrus sp. pada 5 HSA.

6. Insektisida fipronil dan BPMC agak menekan chironomid, dengan nilai IHR ringan dan kecepatan rekolonisasi 1 HSA pada fipronil dan 3 HSA pada BPMC.

\section{DAFTAR PUSTAKA}

Al-Shami, SA, MR Salmah, AA Hassan, and MNS Azizah. 2010. Temporal distribution of larval Chironomidae (Diptera) in experimental rice fields in Penang, Malaysia. J. Asia-Pacific Entomol. 13: 17-22.

Baehaki, SE dan IN Widiarta. 2008. Hama wereng dan cara pengendaliannya pada tanaman padi. Hlm. 347-384 dalam Padi 2, Inovasi Teknologi Produksi. (AA Daradjat, Ed.). LIPI Press, Anggota IKAPI. ISBN 978-979799-392-4.

Baehaki, SE. 2010. Evaluasi potensi dan komposisi parasitoid telur penggerek padi putih di pertanaman padi pada agroekosistem berbeda. Prosiding Seminar Nasional VI Perhimpunan Entomologi Indonesia. Hlm. 233-249.

Baehaki, SE. 2013. Hama penggerek batang padi dan teknologi pengendalian. IPTEK Tanaman Pangan. 8(1): 1-14.

Baehaki, SE, D Munawar, dan E Kiswanto. 2012. Pengaruh pola tanam dan pupuk organik terhadap perkembangan wereng cokelat dan pengkayaan musuh alami. Seminar Hasil Penelitian BB Padi, 10-11 Agustus 2012. $16 \mathrm{hlm}$.

Boutin, C, PA Martin, and A Baril. 2009. Arthropod diversity as affected by agricultural management (organic and conventional farming), plant species and landscape context. Ecoscience. 16: 492-501.

Chakraborty, K. 2010. Comparative assessment of the efficacy of yellow stem borer (Scirpophaga incertulas) egg parasitoid in pesticide treated and untreated paddy field at Uttar Dinajpur, West Bengal, India. Middle-East Journal of Scientific Research. 6(3): 268-270.

Chakraborty, K. 2012. Relative composition of egg parasitoid species of yellow stem borer, Scirpophaga incertulas Wlk. in paddy field at Uttar Dinajpur, West Bengal, India. Current Biotica. 6(1): 42-52. 
Cloyd, RA and JA Bethke. 2011. Impact of neonicotinoid insecticides on natural enemies in greenhouse and interiorscape environments. Pest Manag. Sci. 67(1): 3-9.

Das, S, S Roy, and A Mukhopadhyay. 2010. Diversity of arthropod natural enemies in the tea plantations of North Bengal with emphasis on their association with tea pests. Current Science. 99: 1457-1463.

Desneux, N, A Decourtye, and JM Delpuech. 2000. The sublethal effects of pesticides on beneficial arthropods. Annual Review of Entomology. 52: 81-106.

Dinter, A, KE Brugger, NM Frost, and MD Woodward. 2009. Chlorantraniliprole (Rynaxypyr): A novel DuPont insecticide with low toxicity and low risk for honey bees (Apis mellifera) and bumble bees (Bombus terrestris) providing excellent tools for uses in integrated pest management. Hazards of pesticides to bees - 10th International Symposium of the ICP-Bee Protection Group. 13 p.

Falcone, JF and LE DeWald. 2010. Comparisons of arthropod and avian assemblages in insecticide treated and untreated eastern hemlock (Tsuga Canadensis [L.] Carr) stands in Great Smoky Mountains National Park, USA. Forest Ecology and Management. 260: 856-863.

Faria, MS, AJA Nogueira, and AMVM Soares. 2007. The use of Chironomus riparius larvae to assess effects of pesticides from rice fields in adjacent freshwater ecosystems. Ecotoxicology and Environmental Safety. 67: 218-226.

Fritz, LL, EA Heinrichs, V Machado1, TF Andreis, M Pandolfo, SM de Salles, JV deOliveira, and LM Fiuza. 2013. Impact of lambdacyhalothrin on arthropod natural enemy populations in irrigated rice fields in southern Brazil. International Journal of Tropical Insect Science. 33(3): 178-187.

Gangurde, S. 2007. Aboveground arthropod pest and predator diversity in irrigated rice (Oryza sativa L.) production systems of the Philippines. Journal of Tropical Agriculture. 45: 1-8.

Geiger, F, FL Wackers, and F Bianchi. 2009. Hibernation of predatory arthropods in semi-natural habitats. BioControl. 54: 529535.

Marchiori, A, J Baumart, and S Santos. 2012. Immatures of Chironomidae (Insecta Diptera) under the action of pesticides in irrigated rice field. Ecohydrology and Hydrobiology. 12(1): 43-52.

Marheni. 2004. Kemampuan beberapa predator pada pengendalian wereng batang coklat (Nilaparvata lugens Stal.). Jurnal Natur Indonesia. 6(2): 84-86.

Martinou, AF, N Seraphides, and MC Stavrinides. 2014. Lethal and behavioural effects of pesticides on the insect predator Macrolophus pygmaeus. Chemosphere. 96: 167-173.

Rodrigues, ENL., MS Mendonça Jr, LL Fritz, EA Heinrichs, and L Fiuza. 2013. Effect of the insecticide Lambdacyhalothrin on rice spider populations in southern Brazil. Zoologia. 30(6): 615-622.

Roubos, CR, CR Saona, R Holdcraft, KS Mason, and $\mathrm{R}$ Isaacs. 2014. Relative toxicity and residual activity of insecticides used in blueberry pest management: mortality of natural enemies. J. Econ. Entomol. 107(1): 277-285.

Ruay-aree, S. 2002. Impact of Insecticide on The Natural Enemies, Arthropod Guild Communities and Species Diversity in Rice Ecosystem. Available online at http://agris.fao.org/agrissearch/search.do?recordID=TH2005000836. (accessed February 2016).

Torres, J. B. 2012. Insecticide resistance in natural enemies - seeking for integration of chemical and biological controls. J. Biofert. Biopest. 3(104):1-3.

Turchen, LM, V Golin, AR Butnariu, RNC Guedes, and MJB Pereira. 2016. Lethal and sublethal effects of insecticides on the egg parasitoid Telenomus podisi (Hymenoptera: Platygastridae). J. Econ. Entomol. 109(1): 84-92.

Wang, HY, Y Yang, JY Sua, JL Shen, CF Gao, and YC Zhu. 2008. Assessment of the impact of insecticides on Anagrus nilaparvatae (Pang et Wang) (Hymenoptera: Mymanidae), an egg parasitoid of the rice planthopper, Nilaparvata lugens (Hemiptera: Delphacidae). Crop Protection. 27: 514-522. 